\title{
Ichthyofauna from "serranias costeiras" of the Ribeira de Iguape River basin, Southeast Brazil
}

\author{
Mauricio Cetra ${ }^{1 *}$, George Mattox ${ }^{2}{ }^{\mathbb{D}}$, Perla Bahena Romero ${ }^{3}$, Stephanie Hernández Escobar ${ }^{3}$, Euriluce \\ Aparecida Guimarães ${ }^{3} \&$ Rubens Antonio Felipe Turin ${ }^{1}$ \\ ${ }^{1}$ Universidade Federal de São Carlos, Departamento de Ciências Ambientais, Sorocaba, SP, Brasil. \\ ${ }^{2}$ Universidade Federal de São Carlos, Departamento de Biologia, Sorocaba, SP, Brasil. \\ ${ }^{3}$ Universidade Federal de São Carlos, Programa de Pós-Graduação em Planejamento e Uso de Recursos \\ Renováveis, Sorocaba, SP, Brasil. \\ *Corresponding author: Mauricio Cetra, e-mail: mcetra@ufscar.br
}

CETRA, M., MATTOX, G., ROMERO, P.B., ESCOBAR, S.H., GUIMARÃES, E.A., TURIN, R.A.F. Ichthyofauna from "serranias costeiras" of the Ribeira de Iguape River basin, Southeast Brazil. Biota Neotropica 20(4): e20200094. https://doi.org/10.1590/1676-0611-BN-2020-0994

\begin{abstract}
The Ribeira de Iguape River basin has about 100 fish species. This study aimed to characterize the fish community from "serranias costeiras" of the Ribeira de Iguape River basin. Samplings were conducted with electrofishing during the dry season in the years 2018-2019. The sampling effort consisted of 30 streams stretches. As a result, 50 species were captured, distributed in 37 genera, 11 families, and six orders. The species richness estimate (SChao1) was 57 species, and the coverage estimate for the entire data set was $\mathrm{C}=0.998$. Harttia kronei and Chasmocranus lopezae are endemic species and can be used as bioindicators of streams in this river basin. We captured approximately nine species by stream stretch. Beta diversity was found to be more critical for gamma diversity than alpha diversity. This finding highlights the streams environmental heterogeneity importance for maintaining regional fish diversity. We captured eight individuals of the threatened species Spintherobolus papilliferus and this indicates an expansion in the geographic distribution of this species.
\end{abstract}

Keywords: fish communities, IUCN, endemic species.

\section{Ictiofauna das "serranias costeiras" da bacia do rio Ribeira de Iguape, sudeste do Brasil}

Resumo: A bacia hidrográfica do rio Ribeira de Iguape possui cerca de 100 espécies de peixes. O objetivo deste estudo foi caracterizar a comunidade de peixes de riachos das serranias costeiras da bacia do rio Ribeira de Iguape. O levantamento das espécies foi realizado com uso de pesca elétrica durante a estação seca de 2018-2019. As coletas ocorreram em 30 trechos de riachos. Foram capturadas 50 espécies distribuídas em 37 gêneros, 11 famílias e seis ordens. A estimativa de riqueza de espécies $\left(\mathrm{S}_{\text {Chaol }}\right)$ foi de 57 espécies e a estimativa de cobertura para todo o conjunto de dados foi de $\mathrm{C}=0,998$. Harttia kronei e Chasmocranus lopezae são espécies endêmicas e podem ser usadas como bioindicadores para os riachos nesta bacia hidrográfica. Capturamos aproximadamente nove espécies por trecho de riacho. A diversidade beta foi considerada mais importante para a diversidade gama do que a diversidade alfa. Esse resultado destaca a importância da heterogeneidade ambiental dos riachos para manter a diversidade regional de peixes. Capturamos seis indivíduos de uma espécie ameaçada Spintherobolus papilliferus e, dessa forma, ocorreu uma expansão da distribuição geográfica desta espécie.

Palavras-chave: comunidades de peixes, IUCN, espécies endêmicas. 


\section{Introduction}

A set of ecosystems and a mosaic of forest formations form the Atlantic Forest biome (MMA 2020). A large number of independent hydrographic basins, sea-level fluctuations, and stream capture events (Menezes et al. 2007) help us to understand the richness and distribution of about 270 freshwater fish species, 190 of which are considered endemic species (Abilhoa et al. 2011). Besides, estimates point to the existence of 500 species in the Atlantic Forest biome (Thomaz \& Knowles 2018), suggesting that our knowledge on the freshwater ichthyofauna is far from being completed. On the other hand, about 100 species are considered threatened (Castro \& Polaz 2020) since only $12.4 \%$ of the forest that initially existed remains. Although this biome represents only $15 \%$ of the national territory, about $70 \%$ of Brazilians reside in this biome, concentrating $80 \%$ of the national economic production (MMA 2020).

The Ribeira de Iguape River basin is the Southern limit of the Eastern coastal drainages (Langeani et al. 2009) with a complex dendritic structure, relatively small but isolated, emptying straight into the Atlantic Ocean. A low human population occupies it, and Small Hydropower Plants promote hydrological fragmentation (CBH-RB 2016). Among these coastal drainages, the Ribeira de Iguape River basin has large areas protected and well preserved (Oyakawa et al. 2006).

In the state of São Paulo, there are 391 fish species, around $15 \%$ of the species richness estimated for Brazil (Oyakawa \& Menezes 2011). Of this total, 97 species occur in the Ribeira de Iguape River basin. Since 2011, at least six species can be added to this list: Pimelodus multicratifer Ribeiro, Lucena \& Oyakawa 2011, Deuterodon oyakawai (Santos \& Castro 2014), Atlantirivulus ribeirensis Costa 2014, Ituglanis amphipotamus Mendonça, Oyakawa \& Wosiacki 2018, Trichomycterus lauryi Donin, Ferrer \& Carvalho 2020 and Microcambeva filamentosa Costa, Katz \& Vilardo 2020. This diversity is associated with betweenhabitat (beta) diversity among streams (Teshima et al. 2016).

As suggested by Casatti et al. (2008), from the ichthyological point of view, an ongoing study will comprise the following actions: (i) list pertinent information from the Ribeira de Iguape River basin representing records of activities threatening the maintenance of the ichthyofauna biotic integrity, especially the existence of micro-basins impoundments that broke the hydrological connectivity of the system; (ii) promote an ecological study of the headwater fish species of particular interest due to the sharing with adjacent basins.

Fauna inventories generate essential information for the knowledge of patterns of richness and species distribution. They support decision making in projects that will impact the environment (Silveira et al. 2010) and will assist in the definition of public policies (Fapesp 2008). In these studies, it is possible to identify the environmental heterogeneity, sites with species richness, endangered, rare, and endemic species, and detect bioindicators species with a high abundance and occurrence.

With the present list of species, our objective is to estimate the species richness and verify the contribution of beta diversity. We checked the occurrence of endemic and threatened species, and suggest possible bioindicators fish species in streams present at Serras do Mar and Paranapiacaba, and the plains of upper Ribeira de Iguape River basin.

\section{Material and Methods}

\section{Study area}

The Ribeira de Iguape River basin covers an area of approximately $27.000 \mathrm{~km}^{2}$, comprising 13 municipalities from Paraná State and 23 from São Paulo State, which together house an estimated population of over 990.000 inhabitants (CBH-RB 2016).

In the São Paulo State, the Water Resources Management Unit (Unidade de Gerenciamento dos Recursos Hídricos - UGRHI 11) corresponds to the Ribeira de Iguape River basin and Southern Coastal drainages. It presents one of the most extensive natural vegetation covers in the State of São Paulo, with $12.256 \mathrm{~km}^{2}$ of native forest remaining occupying approximately $72 \%$ of the area of UGRHI 11 (CBH-RB 2016). The average precipitation in the UGRHI 11 is $1400 \mathrm{~mm} /$ year. The UGRHI 11 has 37 Conservation Units, 15 beings of Integral Protection, and 22 of Sustainable Use (CBH-RB 2016).

The Ribeira de Iguape River basin can be divided into two great domains: the coastal plains constituted mainly by cenozoic sedimentary deposits and the "serranias costeiras" formed by ancient crystalline rocks. Within these crystalline rocks, through more hilly terrain, lay the systems of mountains and escarpments characterizing the Serras do Mar and Paranapiacaba with Conservation Units, and a set of hills and summit surfaces of the plains of upper Ribeira de Iguape River basin (Ross 2002).

The main rivers in the basin are the Ribeira de Iguape in its lower reaches, and some of the main tributaries such as Açungui, Capivari, Pardo, Turvo, Juquiá, São Lourenço, Jacupiranga, Itapirapuã, Una da Aldeia, and Itariri rivers. The rivers Itapirapuã, Pardo, and Ribeira de Iguape are under the Federal government domain and all the remainder are under state domain (CBH-RB 2016).

\section{Ichthyofauna sampling}

Sampling occurred during the dry season (July - November) of 2018 and 2019 , between $10 \mathrm{~h}$ and $18 \mathrm{~h}$. In the dry season, the associations between the fish assemblage and environmental structure are more evident in this period (Pinto et al. 2006). Also, it is crucial to control the effect of temporal variation.

The ichthyofauna was sampled in 30 transects of $70 \mathrm{~m}$ of streams in the "serranias costeiras" (Figure 1) using electrofishing (LR-24 Electrofisher - Smith-Root) in the downstream-upstream direction with a single passage and without contention nets (Permits: SISBIO 13352-1/IBAMA/MMA and Proc. SMA 006.674/2018). These transects belong to 16 micro-basins: Alto Ribeira, Teixeira, Figueira, Criminosas, Catas Altas, Palmital, Monte Alegre, Pilões, Taquari, Pedro Cubas, Etá, Quilombo, Preto, Açungui, Ribeirão Fundo, and Juquiá-Guaçu (Table 1 and Figure 2).

Fish were anesthetized with eugenol (clove oil) and fixed for at least 48 hours in $10 \%$ formalin. All specimens are stored in $70 \%$ ethanol in the collection of Laboratório de Ecotoxicologia Animal e Análise de Integridade Ambiental of UFSCar - Sorocaba. Voucher specimens of all species were deposited in the ichthyological collection of Laboratório de Ictiologia do Departamento de Zoologia e Botânica of UNESP - câmpus de São José do Rio Preto (DZSJRP 22983 23048). Photographs of most species were taken using a DSLR camera with a $60 \mathrm{~mm}$ macro lens on preserved specimens. 


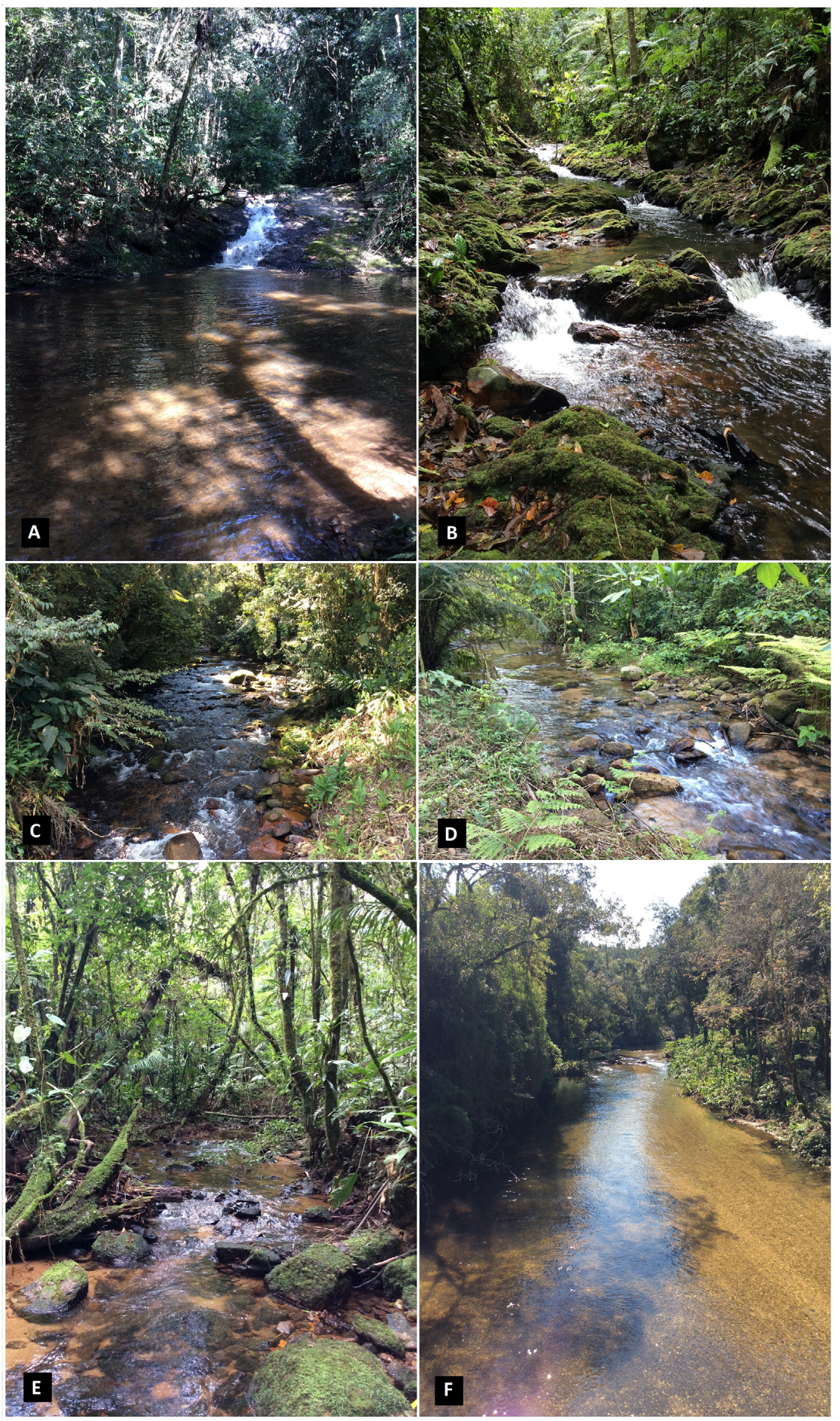

Figure 1. Representative stream stretch sampled from "serranias costeiras" of the Ribeira de Iguape River basin, Southeast Brazil. a) Afluente do Juquiá-Guaçu, b) Rio Ouro Fino, c) Rio Corujas, d) Ribeirão Fundo, e) Rio Bonito, f) Rio Itapirapuã. 
Table 1. Geographic information of sampling transects. Conservation Units (CU): Parque Estadual do Jurupará (PEJU), Área de Proteção Ambiental da Serra do Mar (APASM), Parque Estadual Carlos Botelho (PECB), Parque Estadual Intervales (PEI), Área de Proteção Ambiental Quilombos do Médio Ribeira (APAQMR).

\begin{tabular}{|c|c|c|c|c|c|c|}
\hline Stream & Micro-basin & Lat. & Long. & $\mathrm{CU}$ & Municipality & State \\
\hline das Cachoeiras & Juquiá-Guaçu & -23.978 & -46.891 & - & Juquitiba & SP \\
\hline A. Juquiá & Juquiá-Guaçu & -23.987 & -47.003 & - & Juquitiba & SP \\
\hline Laranjeiras & Juquiá-Guaçu & -23.842 & -47.061 & - & Juquitiba & SP \\
\hline Cachoeira do Chá & Açungui & -24.029 & -47.575 & APASM & Tapiraí & SP \\
\hline Corujas & Açungui & -24.060 & -47.589 & APASM & Juquiá & SP \\
\hline Ipiranga & Preto & -24.164 & -47.850 & APASM & Sete Barras & SP \\
\hline Preto & Preto & -24.192 & -47.891 & APASM & Sete Barras & SP \\
\hline da Serra & Quilombo & -24.185 & -47.933 & PECB & Sete Barras & SP \\
\hline A. Preto & Preto & -24.172 & -47.962 & PECB & S.M. Arcanjo & SP \\
\hline Temível & Preto & -24.129 & -47.985 & PECB & S.M. Arcanjo & SP \\
\hline Pedro Cubas & Pedro Cubas & -24.461 & -48.307 & APAQMR & Eldorado & SP \\
\hline São Pedro & Taquari & -24.290 & -48.369 & PEI & Ribeirão Grande & SP \\
\hline Carmo & Pilões & -24.306 & -48.414 & PEI & Ribeirão Grande & SP \\
\hline Itacolomi & Pilões & -24.474 & -48.469 & APAQMR & Iporanga & SP \\
\hline Pilões & Pilões & -24.453 & -48.509 & APAQMR & Iporanga & SP \\
\hline Iporanga & Monte Alegre & -24.521 & -48.585 & - & Iporanga & SP \\
\hline Palmital & Palmital & -24.573 & -48.873 & - & Apiaí & SP \\
\hline Claro & Catas Altas & -24.441 & -49.096 & - & Barra do Chapéu & SP \\
\hline Criminosas & Criminosas & -24.551 & -49.202 & - & Itapirapuã Paulista & SP \\
\hline Itapirapuã & Figueira & -24.565 & -49.318 & - & Itapirapuã Paulista & SP \\
\hline
\end{tabular}
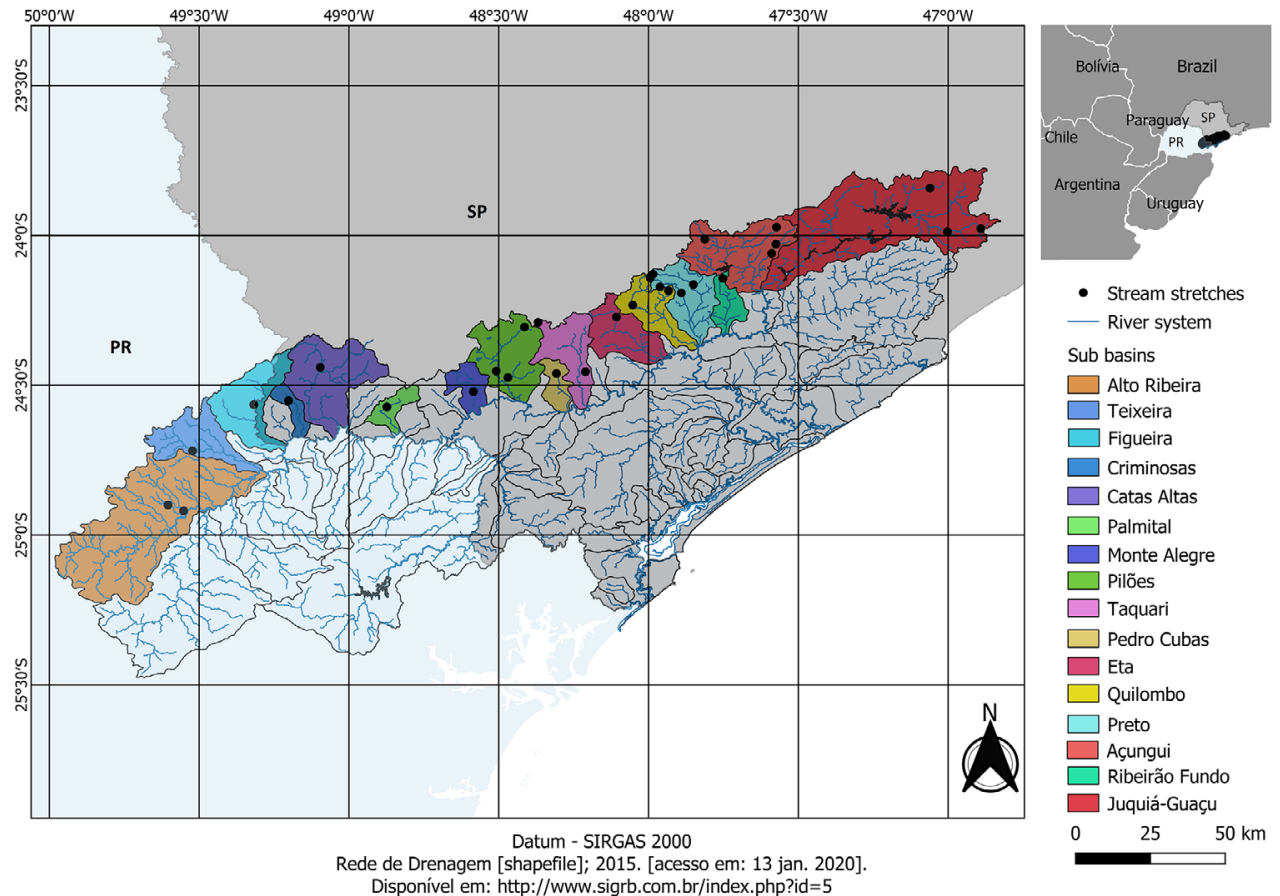

Figure 2. Sub-basins and stream stretch sampled in the Ribeira de Iguape River basin. 


\section{Data analysis}

The Chao method was used to estimate species richness (SChaol \pm standard error) and verify sampling effort. The diversity was partitioned into its components, and the statistical significance of alpha and beta was obtained. The analysis was carried with the packages SpadeR (Chao \& Hsieh 2015) and vegan (Oksanen et al. 2019) in the $R$ environment (R CoreTeam 2020). To verify fish species bioindicators, we used the frequency of occurrence. Information on endemic and threatened species was based on Oyakawa et al. (2006), Buckup et al. (2007), Menezes et al. (2007), Oyakawa \& Menezes (2011) and Fricke et al. (2020) and Decree No. 60.133 , dealing with threatened species of wild fauna in the State of São Paulo (São Paulo 2014).

\section{Results and Discussion}

Approximately $9 \mathrm{~kg}$ of fish were caught, with 3281 individuals representing 50 species, 37 genera, 11 families, and six orders (Table 2). Although the ichthyofauna from the State of São Paulo is relatively well known (Oyakawa \& Menezes 2011), there are still many taxa to be better studied, such as the cases of Astyanax, Characidium, and Trichomycterus. Around four per cent of the individuals did not have their specific identification from genera Astyanax, Characidium, Hypostomus, Rineloricaria, and Trichomycterus. Oyakawa et al. (2006) had already mentioned some Astyanax that could be new species, and the genus needs a taxonomic review within the Ribeira de Iguape River basin to elucidate the species richness in that drainage. A single specimen of armoured catfish was a juvenile and could not be identified beyond the family level.

Table 2. Stream fishes from "serranias costeiras" of the Ribeira de Iguape River basin. Endemics species are in bold (Oyakawa et al. (2006), Buckup et al. (2007), Menezes et al. (2007), Oyakawa \& Menezes (2011), Fricke et al. (2020). Sub basins: Alto Ribeira (ARib), Teixeira (Tei), Figueira (Fig), Criminosas (Cri), Catas Altas (CAlt), Palmital (Pal), Monte Alegre (Male), Pilões (Pil), Taquari (Taq), Pedro Cubas (PCub), Etá (Eta), Quilombo (Qui), Preto (Pre), Açungui (Acu), Ribeirão Fundo (RFun), Juquiá-Guaçu (JGua). Threatened taxa * ICMBio (2018) and ** São Paulo (2014) without local identification. Voucher identification (DZSJRP).

Order/Family/Species ARib Tei Fig Cri CAlt Pal MAle Pil Taq PCub Eta Qui Pre Acu RFun JGua DZSJRP

\section{CHARACIFORMES}

\section{Characidae}

Astyanax janeiroensis Eigenmann, 1908

Astyanax ribeirae Eigenmann, 1911 Bryconamericus microcephalus (Miranda Ribeiro, 1908)

Deuterodon iguape Eigenmann, 1907

Hollandichthys multifasciatus (Eigenmann \& Norris, 1900)

Hyphessobrycon bifasciatus Ellis, 1911

Hyphessobrycon reticulatus Ellis, 1911

Mimagoniates microlepis (Steindachner, 1877)

Spintherobolus papilliferus Eigenmann, 1911*

\section{Crenuchidae}

Characidium lanei Travassos, 1967

Characidium lauroi Travassos, 1949 **

Characidium pterostictum Gomes, 1947

Characidium schubarti Travassos, 1955 **

\section{GYMNOTIFORMES}

\section{Gymnotidae}

Gymnotus pantherinus (Steindachner, 1908)

\section{SILURIFORMES}

\section{Callichthyidae}

Scleromystax barbatus (Quoy \& Gaimard, 1824)

\section{Heptapteridae}

Acentronichthys leptos Eigenmann \& Eigenmann, 1889

Chasmocranus lopezae Miranda Ribeiro, 1968

Pimelodella transitoria Miranda Ribeiro, 1907

Rhamdia quelen (Quoy \& Gaimard, 1824)

Rhamdioglanis transfasciatus Miranda Ribeiro, 1908

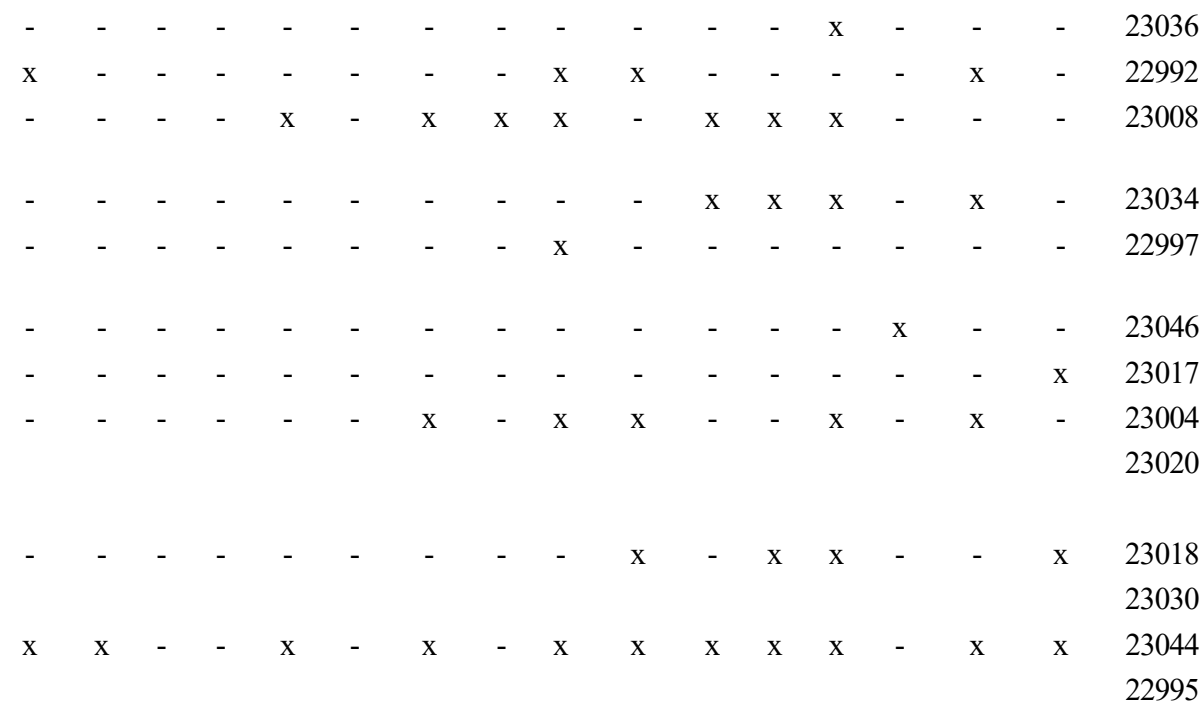

23036

2992

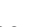

22997

3046

23004

23020

23018

3044

(1)

22996

23011

23032

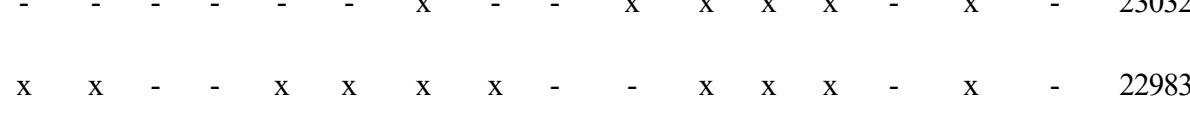

$\mathrm{x}-\mathrm{-}-\mathrm{-}-\mathrm{x}-\mathrm{x}-\mathrm{x}-\mathrm{x}-\mathrm{x}-23039$



$\begin{array}{lllllllllllllllllll}\mathrm{x} & - & - & - & - & - & \mathrm{x} & \mathrm{x} & \mathrm{x} & \mathrm{x} & \mathrm{x} & \mathrm{x} & \mathrm{x} & - & \mathrm{x} & - & 23041\end{array}$ 
...continue

Order/Family/Species ARib Tei Fig Cri CAlt Pal MAle Pil Taq PCub Eta Qui Pre Acu RFun JGua DZSJRP

Loricariidae

Ancistrus multispinis (Regan, 1912)

Harttia kronei Miranda Ribeiro, 1908

Hisonotus leucofrenatus (Miranda Ribeiro, 1908)

Hypostomus interruptus (Miranda Ribeiro, 1918)

Isbrueckerichthys alipionis (Gosline, 1947)

Isbrueckerichthys duseni (Miranda Ribeiro, 23028

1907) **

Isbrueckerichthys epakmos Pereira \&

Oyakawa, $2003 * *$

Kronichthys lacerta (Nichols, 1919)

Kronichthys subteres Miranda Ribeiro, 1908

Lampiella gibbosa (Miranda Ribeiro, 1908)

Neoplecostomus paranensis Langeani, 1990

Neoplecostomus ribeirensis Langeani, 1990

Parotocinclus maculicauda (Steindachner, 1877)

Pseudotothyris obtusa (Miranda Ribeiro, 1911)

Rineloricaria kronei (Miranda Ribeiro, 1911)

Rineloricaria lima (Kner, 1853)

Schizolecis guentheri (Miranda Ribeiro, 1918)

Pseudopimelodidae

Microglanis cottoides (Boulenger, 1891)

Trichomycteridae

Cambeva davisi (Haseman, 1911)

Cambeva tupinamba (Wosiacki \&

Oyakawa, 2005)

Homodiaetus graciosa Koch, 2002 **

Microcambeva ribeirae Costa, Lima \& Bizerril, 2004

Trichomycterus alternatus (Eigenmann 1917)

Trichomycterus lauryi Donin, Ferrer \& Carvalho, 2020

\section{CYPRINODONTIFORMES}

Poeciliidae

Phalloceros harpagos Lucinda, 2008

Phalloceros reisi Lucinda, 2008

Poecilia vivipara Bloch \& Schneider, 1801

\section{SYNBRANCHIFORMES}

\section{Synbranchidae}

Synbranchus aff. marmoratus Bloch, 1795

\section{CICHLIFORMES}

Cichlidae

Crenicichla iguapina Kullander \& Lucena, 2006 
About $40 \%$ of the specimens are less than $50 \mathrm{~mm}$ in standard length (SL), a common feature in stream fishes occupying small environments and that may complete their life cycles in restricted geographic areas (Castro 1999, Menezes et al. 2007). The orders Siluriformes and Characiformes represented most of the species richness, $61 \%$, and $25 \%$, respectively, reflecting a well-known pattern recognized for South American rivers (Lowe-McConnell 1999).

We have identified about $40 \%$ of the species captured by Barrella et al. (2014) in the portion between Serra de Paranapiacaba and the estuary of Iguape-Cananéia. Around $50 \%$ of the 97 species listed by Oyakawa \& Menezes (2011) checklist for the Ribeira de Iguape River ichthyofauna. Approximately $70 \%$ of the species caught by Oyakawa et al. (2006) in streams from the Conservation Units of São Paulo State in the Ribeira de Iguape River basin. On the other hand, we sampled around twice the number of species identified from Frota et al. (2019) captured in headwater streams of the Ponta Grossa Arch in the Paraná State portion of Ribeira de Iguape River basin.

The species richness estimates (Schao1) was 57, with a 95\% confidence interval of $(51-92)$. The coverage estimate for the entire data set was $\mathrm{C}=0.998$. The coverage estimate is an objective measure of sample completeness. It represents the estimated fraction of the whole population of individuals in the community that belong to the species represented in the sample (Chao \& Chiu 2014). This result indicates sampling effort with few species with one individual. With the abundance data, the estimated coefficient of variation was 1.56 that characterize the degree of heterogeneity for species discovery probabilities $(\mathrm{CV}=0$ would mean that all species are homogeneous) (Chao \& Chiu 2014).

Species richness ranged from 2 to 20 per stretch stream, with mean of 9.1 species. The comparison between the observed data and those generated under the null model revealed that alpha diversity (i.e., species diversity within a stream) showed lower species richness than expected by chance. Tropical streams usually have little species richness mainly due to small water volume (Gerhard et al. 2009, Súarez 2011). On the other hand, the diversity difference betweenstream (i.e., beta diversity) was higher than expected under the null model (Figure 3). Beta diversity was found to be more critical for total diversity (i.e., gamma diversity) than the average local diversity. These findings highlight the importance of streams environmental heterogeneity for maintaining regional fish diversity (Erös 2007, Casatti et al. 2009, Teshima et al. 2016).

The Ribeira de Iguape River basin is well known for its endemic fish species (Bizerril \& Lima 2000, Ribeiro 2006) (Table 2 and Figures 4, 5, and 6). Approximately $35 \%$ of the species captured herein are endemic of the Ribeira de Iguape River basin. Harttia kronei and Chasmocranus lopezae are abundant endemic species. Few vertebrate species fulfill multiple criteria for ecosystem health indicator, as most are highly mobile generalists that lack established tolerance levels and correlations with ecosystem changes (Hilty \& Merenlender, 2000). These authors indicated three general categories for selecting indicator taxa: (1) baseline information, (2) location information, (3) niche and life history attributes.

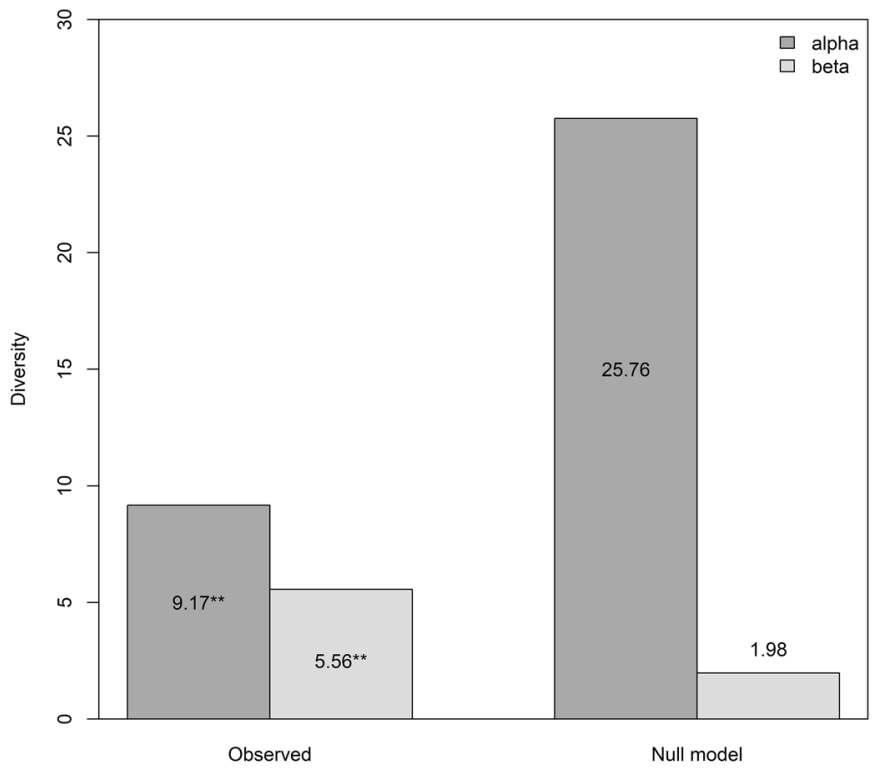

Figure 3. Multiplicative partition of the gamma diversity (** indicates statistically significant differences between observed and null model values).

We suggest baseline studies with $H$. kronei and $C$. lopezae regarding their tolerance to impacts and ecosystem changes, mobility, population fluctuation, reproductive rates, and food preference since they are not migratory, have a small body and are easy to find. With this information, biomonitoring programs can use these species as indicators for the biological conservation status of streams in this river basin.

Three species are new records for the Ribeira de Iguape River basin: Spintherobolus papilliferus from headwaters of the Tietê River basin, Characidium lauroi from the Paraíba do Sul River basin, and Neoplecostomus paranensis from headwaters of the Upper Paraná River basin (Buckup et al. 2007). Frota et al. (2019) captured Astyanax bifasciatus, an endemic species of the Iguaçu River basin in the headwaters of Ribeira de Iguape River. The events of headwater capture between coastal drainages and those that flow into the interior of the continent could explain these biogeographic patterns (Serra et al. 2005, Frota et al. 2019). This hypothesis remains to be tested in future studies.

We captured eight individuals of Spintherobolus papilliferus that is considered a threatened species (Portaria MMA n ${ }^{\circ} 445 / 2014$ ) belonging to the IUCN category "Critically Endangered", facing a very high risk of extinction in the wild (CR - B2ab(ii, iii, iv)). Spintherobolus papilliferus is a rare and endemic species of the headwaters of the upper Tietê River basin, São Paulo state (Weitzman \& Malabarba 1999, Akama et al. 2018). This record indicates an expansion in the species distribution which will be approached in a more detailed study.

The high endemicity of Ribeira de Iguape River basin coped with new records of species, the presence of threatened species, the existence of putatively new taxa, and the high beta diversity raises concerns about the conservation of its ichthyofauna. 


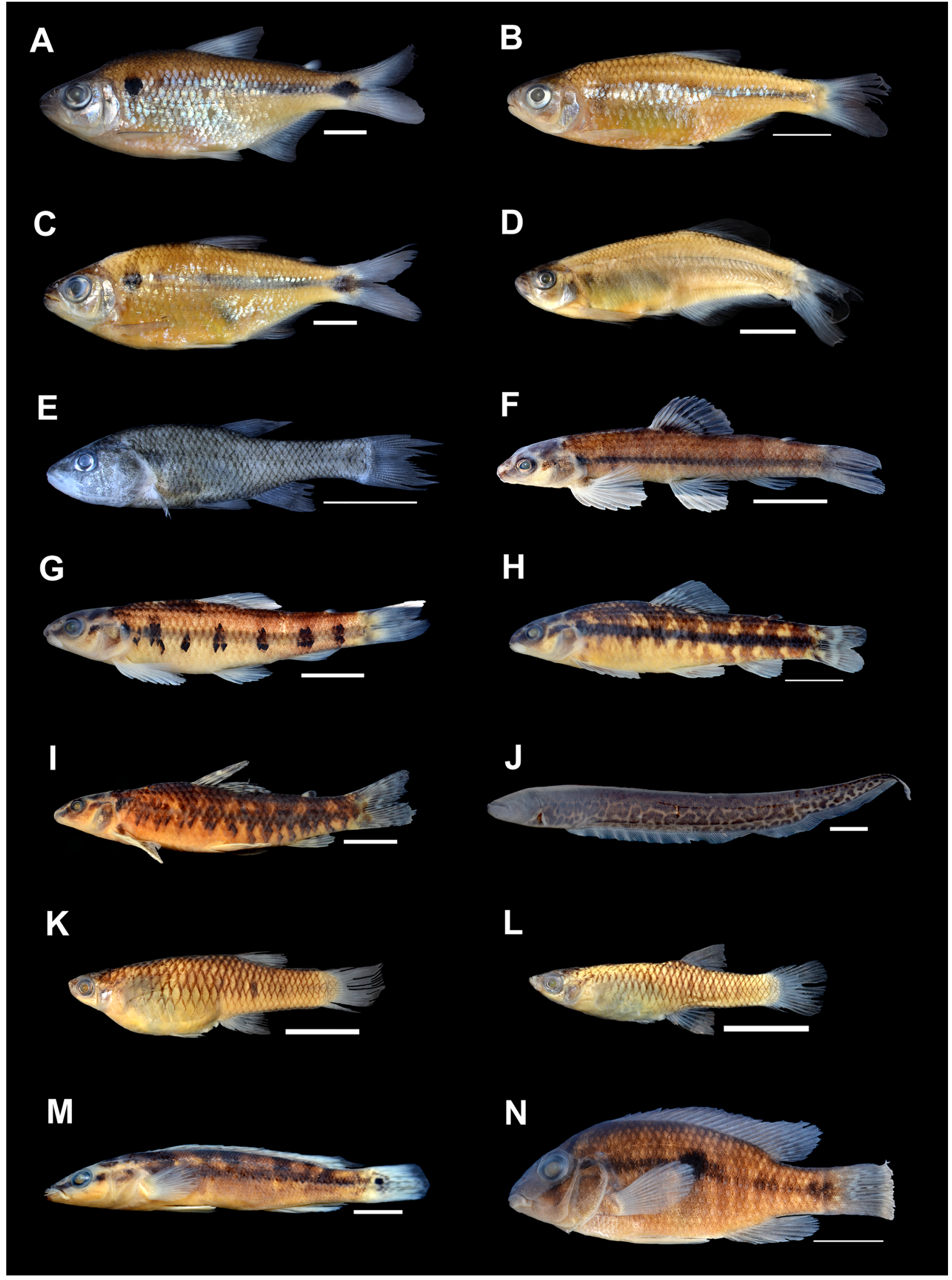

Figure 4. Some fishes sampled in the present study. A: Astyanax ribeirae; B: Bryconamericus microcephalus; C: Deuterodon iguape; D: Mimagoniates microlepis; E: Spintherobolus papilliferus; F: Characidium lanei; G: Characidium lauroi; H: Characidium pterostictum; I: Characidium schubarti; J: Gymnotus pantherinus; K: Phalloceros harpagos; L: Phalloceros reisi; M: Crenicichla iguapina; N: Geophagus iporangensis. Scales $=1 \mathrm{~cm}$. 


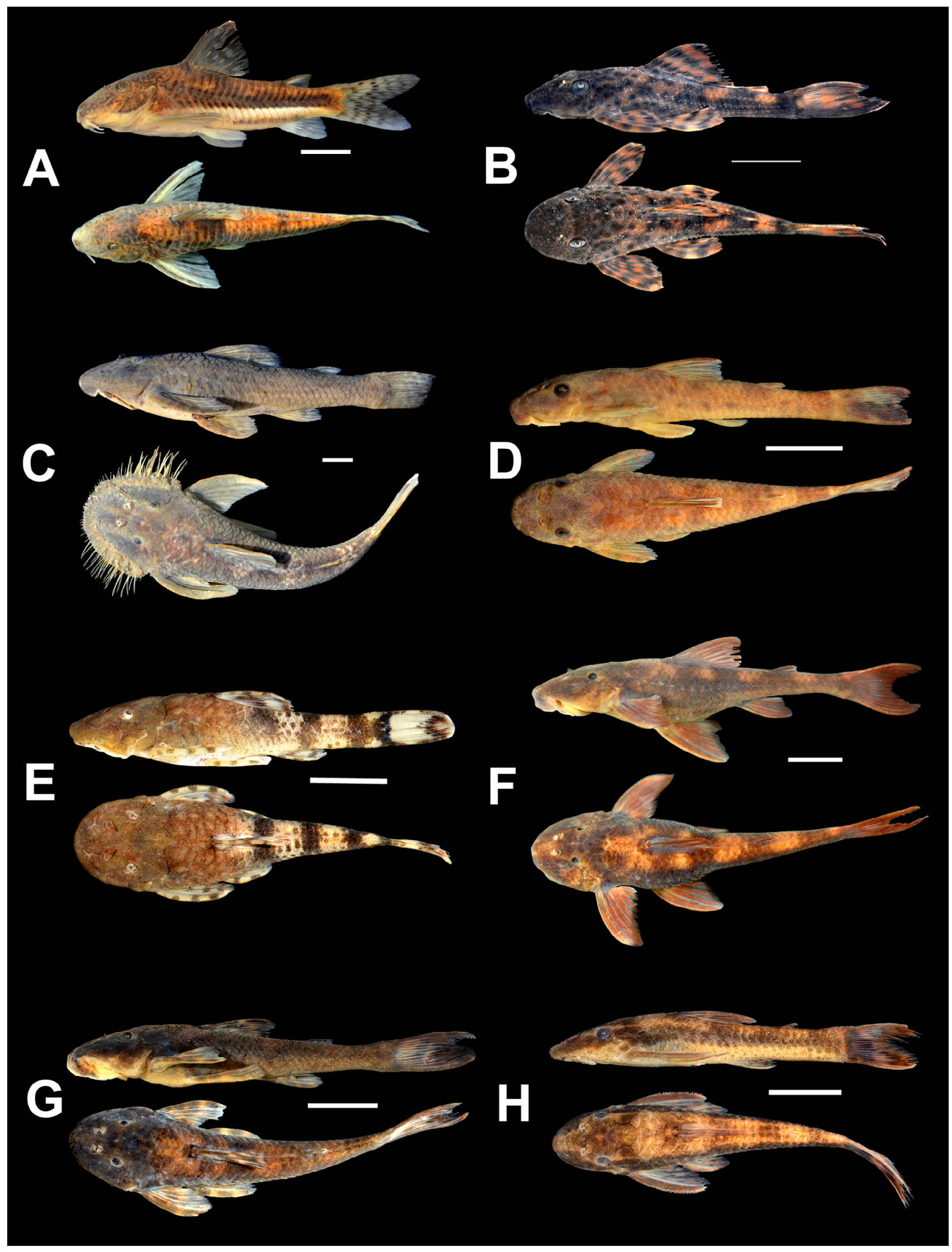

Figure 5. Some Siluriformes of the families Callichthyidae and Loricariidae sampled in the present study. A: Scleromystax barbatus; B: Hypostomus interruptus; C: Isbrueckerichthys duseni; D: Kronichthys lacerta; E: Lampiella gibbosa; F: Neoplecostomus paranensis; G: Neoplecostomus ribeirensis; H: Parotocinclus maculicauda. . Scales $=1 \mathrm{~cm}$. 


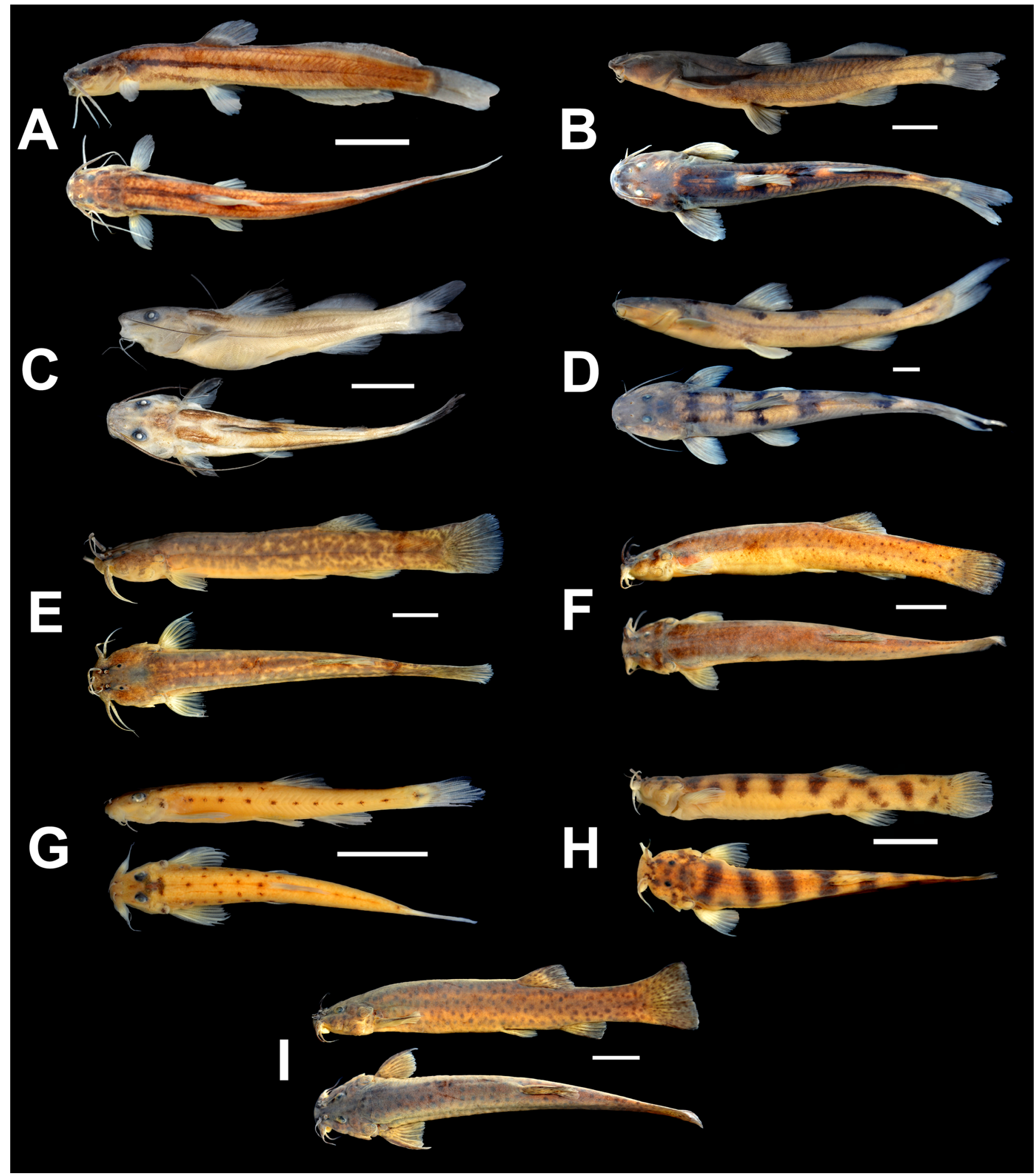

Figure 6. Some Siluriformes of the families Heptapteridae and Trichomycteridae sampled in this study. A: Acentronichthys leptos; B: Chasmocranus lopezae; C: Pimelodella transitoria; D: Rhamdioglanis transfasciatus; E: Cambeva davisi; F: Cambeva tupinamba; G: Microcambeva ribeirae; H: Trichomycterus alternatus; I: Trichomycterus lauryi. Scales $=1 \mathrm{~cm}$. 


\section{Acknowledgments}

We are grateful to Fundação de Amparo à Pesquisa do Estado de São Paulo for financial support (FAPESP, 2017/25860-3) and TT-III fellowship to RAFT (2018/19872-1), and to Francisco Fogaça Balboni, manager of Parque do Zizo. Karen Ventura aided in the photographs.

\section{Author Contributions}

Mauricio Cetra: Contribution to the concept and design of the study, data collection, data analysis and interpretation, preparation of the manuscript, critical review adding intellectual content.

George Mattox: Contribution to the concept of the study, data analysis and interpretation, preparation of the manuscript, critical review adding intellectual content.

Perla Bahena Romero: Contribution to the data collection, data analysis and interpretation.

Stephanie Hernández Escobar: Contribution to the data collection, data analysis and interpretation.

Euriluce Aparecida Guimarães: Contribution to the data collection, data analysis and interpretation.

Rubens Antonio Felipe Turin: Contribution to the data collection, data analysis and interpretation.

\section{Conflicts of Interest}

The authors declare that they have no conflict of interest related to the publication of this manuscript.

\section{References}

ABILHOA, V., BRAGA, R.R., BORNATOWSKI, H., \& VITULE, J.R. 2011 Fishes of the Atlantic Rain Forest streams: ecological patterns and conservation. Changing diversity in changing environment. InTech, Rijeka, p.259-282.

AKAMA, A., NETTO-FERREIRA, A.L., ZANATA, A.M., CALEGARI, B.B., FIGUEIREDO, C.A.A., ALVES, C.B.M., CRAMER, C.A., ZAWADZKI, C.H., RÖPKE, C.P., MOREIRA, C.R., GUBIANI, E.A., DARIO, F.D., VIEIRA, F., MARTINS, F.O., BECKER, F.G., CARVALHO, F.R., MELO, F.A.G., LIMA F.C.T., LANGEANI, F., VARELLA, H.R., FICHBERG, I., SOUSA, L.M., SILVA, L.V.V., PY-DANIEL, L.H.R., SARMENTOSOARES, L.M., TENCATT, L.F.C, SILVA, L.F.D., BRITTO, M.R., LOEB, M.V., OYAKAWA, O.T., ALBORNOZ, P.C.L., CARVALHO, P.H., OTA, R.P., OTA, R.R., BRITZKE, R., CASTRO, R.M.C., REIS, R.E., PINHEIRO, R.F.M., SOUZA-LIMA, R., DEBONA, T., CARVALHO, T.P., ABILHOA, V., FRANA, V.A., GOMES, V.N., GRAÇA, W.J., OHARA, W.M. \& WOSIACKI, W.B. 2018. Spintherobolus papilliferus Eigenmann, 1911. In: Instituto Chico Mendes de Conservação da Biodiversidade. Livro Vermelho da Fauna Brasileira Ameaçada de Extinção: Volume VI - Peixes. Brasília: ICMBio, p.26-29.

BARRELlA, W., MARTINS, A.G., PETRERE JR., M. \& RAMIRES, M. 2014. Fishes of the southeastern Brazil Atlantic Forest. Environ. Biol. Fish 87(12): 1367-1376.

BIZERRIL, C.R.S.F. \& LIMA N.R.W. 2000. Levantamento da ictiofauna da bacia do rio Ribeira de Iguape, Brasil. Acta Biol. Leopoldensia, 22(1): 103-110.

CASATTI, L., FERREIRA, C.P. \& CARVALHO, F.R. 2009. Grass-dominated stream sites exhibit low fish species diversity and dominance by guppies: an assessment of two tropical pasture river basins. Hydrobiologia, 632(1): 273-283.

CASATTI, L., LANGEANI, F., MENEZES, N.A., OYAKAWA, O.T. \& BRAGA, F.M.S. 2008. Peixes de água doce. In: Diretrizes para conservação e restauração da biodiversidade no estado de São Paulo (R.R. Rodrigues \& V.L.R. Bononi, eds). Instituto de Botânica, v.1, p.95-98.
CASTRO, R.M.C. 1999. Evolução da ictiofauna de riachos sulamericanos: padrões gerais e possíveis processos causais. In Ecologia de peixes de riachos: estado atual e perspectivas (E.P. Caramaschi, R. Mazzoni, C.R.S.F. Bizerril \& P.R. Peres-Neto, eds). PPGEUFRJ, Rio de Janeiro, p.139-155.

CASTRO, R.M.C. \& POLAZ, C.N.M. 2020. Small-sized fish: the largest and most threatened portion of the megadiverse neotropical freshwater fish fauna. Biota Neotrop., 20(1), e20180683. Epub December 13, 2019.https://doi. org/10.1590/1676-0611-bn-2018-0683

CBH-RB Comitê da Bacia Hidrográfica do Ribeira de Iguape e Litoral Sul. 2016. Relatório Técnico - Fase II (Relatório Final). Projeto: Elaboração do Mapa de Zoneamento da Vulnerabilidade Natural dos Aquíferos da UGRHI-11- RB-250 - Contrato FEHIDRO 171/2014. https://comiterb.websiteseguro.com/app/ rb250/RELATORIO_TECNICO_FINAL_RB250.pdf.

CHAO, A. \& CHIU, C.H. 2014. Species richness: estimation and comparison. Wiley StatsRef: Statistics Reference Online, 1-26.

CHAO, A., MA, K.H., HSIEH, T.C. \& CHIU, C.H. 2016. SpadeR: Species-Richness Prediction and Diversity Estimation with R. R package version 0.1.1.

ERÖS, T. 2007. Partitioning the diversity of riverine fish: the roles of habitat types and non-native species. Freshw. Biol., 52(7): 1400-1415.

FAPESP (2008). Revista Pesquisa FAPESP: Com força da lei. https://revistapesquisa.fapesp.br/com-forca-de-lei/

FRICKE, R., ESCHMEYER, W.N. \& VAN DER LAAN, R. 2020. Eschmeyer's Catalog of Fishes: Genera, Species, References. http://researcharchive.calacademy.org/research/ ichthyology/catalog/fishcatmain.asp. Electronic version accessed 30 June 2020.

FROTA, A., MESSAGE, H.J., OLIVEIRA, R.C., BENEDITO, E., \& GRAÇA, W.J. 2019. Ichthyofauna of headwater streams from the rio Ribeira de Iguape basin, at the boundaries of the Ponta Grossa Arch, Paraná, Brazil. Biota Neotropica, 19(1), e20180666, http://dx.doi.org/10.1590/1676-0611BN-2018-0666.

GERHARD, P., MORAES, R., \& MOLANDER, S. 2004. Stream fish communities and their associations to habitat variables in a rain forest reserve in southeastern Brazil. Environ. Biol. Fishes, 71(4): 321-340.

HILTY, J., \& MERENLENDER, A. 2000. Faunal indicator taxa selection for monitoring ecosystem health. Biol. Conserv., 92(2): 185-197.

LANGEANI, F., BUCKUP, P.A., MALABARBA, L.R., PY-DANIEL, L.H.R., LUCENA, C.A.S., ROSA, R.S., ZUANON, J.A.S., LUCENA, Z.M.S., DE BRITTO, M.R., OYAKAWA, O.T. \& GOMES-FILHO, G. 2009. Peixes de Água Doce. In Estado da arte e perspectivas para a zoologia no Brasil (R.M. Rocha \& W.A.P. Boeger, eds.). Curitiba, Ed. UFPR, p.211-230.

LOWE-MCCONNELL, R. 1999. Estudos Ecológicos de Comunidades de Peixes Tropicais. EDUSP, São Paulo.

MENEZES, N.A., WEITZMAN, S., OYAKAWA, O.T., LIMA, F., CASTRO, R. \& WEITZMAN, M. 2007. Peixes de água doce da Mata Atlântica. Museu de Zoologia/USP; Conservação Internacional; FAPESP; CNPq, São Paulo.

MMA, MINISTÉRIO DO MEIO AMBIENTE. 2020. Mata Atlântica. https:// www.mma.gov.br/biomas/mata-at $\% \mathrm{C} 3 \% \mathrm{~A} 2$ ntica_emdesenvolvimento

OKSANEN, J., BLANCHET, F.G., FRIENDLY, M., KINDT, R., LEGENDRE, P., MCGLINN, D., MINCHIN, P.R., O'HARA, R.B., SIMPSON, G.L., SOLYMOS, P., STEVENS, M.H.H., SZOECS, E. \& WAGNER, H. 2019. vegan: Community Ecology Package. R package version 2.5-6. https://CRAN.R-project.org/package=vegan. 
OYAKAWA, O.T. \& MENEZES, N.A. 2011. Checklist dos peixes de água doce do Estado de São Paulo. Biota Neotrop. 11(Supl. 1):19-31. http:// www.biotaneotropica.org.br/v11n1a/en/abstract?inventory+bn00211 $01 \mathrm{a} 2011$.

OYAKAWA, O.T., AKAMA, A., MAUTARI, K.C. \& NOLASCO, J.C. 2006. Peixes de riachos da Mata Atlântica. Neotrópica, São Paulo.

PINTO, P., MORAIS, M., ILHÉU, M., SANDÍN, L. 2006. Relationships among biological elements (macrophytes, macroinvertebrates and ichthyofauna) for different core river types across Europe at two different spatial scales. Hydrobiologia, 566(1): 75-90.

R CORE TEAM. 2020. R: A language and environment for statistical computing. R Foundation for Statistical Computing, Vienna, Austria. https://www.Rproject.org/.

RIBEIRO, A.C. 2006. Tectonic history and the biogeography of the freshwater fishes from the coastal drainages of eastern Brazil: an example of faunal evolution associated with a divergent continental margin. Neotrop. Ichthyol., 4(2), 225-246. https://doi.org/10.1590/S167962252006000200009

ROSS, J. 2002. A Morfogênese da bacia do Ribeira do Iguape e os sistemas ambientais. GEOUSP Espaço E Tempo (Online), 6(2): 21-46. https://doi. org/10.11606/issn.2179-0892.geousp.2002.123770.

SÃO PAULO, ASSEMBLEIA LEGISLATIVA DO ESTADO DE SÃO PAULO. 2014. DECRETO No 60.133, DE 7 DE FEVEREIRO DE 2014. http://www.al.sp.gov.br/repositorio/legislacao/decreto/2014/ decreto-60133-07.02.2014.html
SERRA, J.P., CARVALHO, F.R., \& LANGEANI, F. 2007. Ichthyofauna of the rio Itatinga in the Parque das Neblinas, Bertioga, São Paulo State: composition and biogeography. Biota Neotropica, 7(1) https://doi. org/10.1590/S1676-06032007000100011.

SILVEIRA, L.F., BEISIEGEL, B.M., CURCIO, F.F., VALDUJO, P.H., DIXO, M., VERDADE, V.K., MATTOX, G.M.T. \& CUNNINGHAM, P.T.M. 2010. Para que servem os inventários de fauna? Estudos avançados, 24(68), 173-207.

SÚAREZ, Y.R., SOUZA, M.M., FERREIRA, F.S., PEREIRA, M.J., SILVA, E.A., XIMENES, L.Q.L., AZEVEDO, L.G., MARTINS, O.C. \& LIMA JÚNIOR, S.E. 2011. Patterns of species richness and composition of fish assemblages in streams of the Ivinhema River basin, Upper Paraná River. Acta Limnol. Bras., 23(2): 177-188.

TESHIMA, F.A., MELLO, B.J.G., FERREIRA, F.C., \& CETRA, M. 2016. High $\beta$-diversity maintains regional diversity in Brazilian tropical coastal stream fish assemblages. Fish. Manag. Ecol., 23(6): 531-539.

THOMAZ, A.T. \& KNOWLES, L.L. 2018. Flowing into the unknown: inferred paleodrainages for studying the ichthyofauna of Brazilian coastal rivers. Neotrop. Ichthyol., 16(3), e180019. Epub October 11, 2018.https://doi. org/10.1590/1982-0224-20180019

WEITZMAN, S.H. \& MALABARBA, L.R. 1999. Systematics of Spintherobolus (Teleostei: Characidae: Cheirodontinae) from Eastern Brazil. Ichthyol. Explor. Freshw., 10 (1): 1-43.

Received: 10/03/2020

Revised: 16/09/2020

Accepted: 23/09/2020

Published online: 16/10/2020 